\title{
Quality Assurance Cadre of Assisted Teachers at Miftahul Ulum Lumajang Islamic Boarding School
}

\author{
Ahmad Zarkasyi \\ STIS Miftahul Ulum, Lumajang \\ zarkzee@gmail.com
}

DOI: https://doi.org/10.21154/ sajiem.v2i1.46

\begin{abstract}
Pesantren Miftahul Ulum Lumajang is an institution with quality assurance standards for the regeneration of ulama 'and dai with systemized characteristics. Quality assurance is systematic planning in the application of quality management to ensure that a product or service meets quality requirements from start to finish. This research is qualitative research with a field research approach. In this study, data analysis was carried out since data collection was reviewed as a whole. Based on the research findings, the quality assurance system for the regeneration of auxiliary teachers at the Miftahul Ulum Lumajang Islamic Boarding School is carried out on the dimensions of the guarantee system on the cadre side, the guarantee system on the object of regeneration, namely students, and finally the guarantee system in the Islamic boarding school curriculum.
\end{abstract}

Keywords: Quality Assurance; Cadre; Assisted Teachers; Pesantren

\begin{abstract}
Abstrak
Pesantren Miftahul Ulum Lumajang adalah lembaga yang memiliki standar penjaminan mutu untuk kaderisasi ulama 'dan dai dengan karakteristik yang tersistem. Penjaminan Mutu adalah perencanaan sistematis dalam penerapan manajemen mutu untuk memastikan bahwa suatu produk atau jasa memenuhi persyaratan mutu dari awal sampai akhir. Penelitian ini merupakan penelitian kualitatif dengan pendekatan penelitian lapangan. Dalam studi ini, analisis data dilakukan sejak pengumpulan data diperiksa ulang secara keseluruhan. Berdasarkan temuan penelitian. Berdasarkan temuan penelitian, sistem penjaminan mutu kaderisasi guru bantu di Pondok Pesantren Miftahul Ulum Lumajang dilakukan pada dimensi sistem penjaminan pada pihak pengkader, sistem penjaminan pada objek kaderisasi yaitu santri, dan terakhir adalah sistem penjaminan pada kurikulum pondok pesantren.
\end{abstract}

Kata kunci: Penjaminan Mutu; Kaderisasi; Guru Bantu; Pesantren 


\section{Introduction}

A survey on Indonesian student radicalism conducted by the Setara Institute in 2019 concluded that 35.7 percent of students had radicalism that was new to the level of thought; 2.4 percent have shown intolerance in actions and words 0.3 percent has the potential to become terrorists. ${ }^{1}$ Another survey conducted by the Wahid Institute in August 2017 stated that 11 million people are willing to take radical actions, $0.4 \%$ of Indonesia's population has acted radically, and $7.7 \%$ are willing to act radically if possible. ${ }^{2}$ It is strengthened by the results of Okthariza's research in 2019, which states that 39\% of students in 15 provinces are interested in radicalism and Riau is included in the 15 areas studied. Some of the other provinces are West Java, Lampung, Banten, East Java and Central Kalimantan. ${ }^{3}$

The radicalism movement refers to several research results that show it is caused by two factors: first ideological and non-ideological factors such as poverty, inequality in access to education and health, and distrust of the government. Non-ideological factors are easier to overcome, an example of radicalism caused by poverty. To overcome them is by providing access to education, health and work to live a more decent and prosperous life. The approach to security (security treatment) can only be made temporarily to prevent serious effects that are caused for a moment. Meanwhile, the ideological factor cannot be eradicated in the short term and requires careful planning because it is associated with strong religious beliefs and emotions. The ideological factor can only be permanently eradicated through the entrance to education (gentle treatment) utilizing evolutionary deradicalization involving all elements. ${ }^{4}$

The existence of Islamic boarding schools during society plays an essential role in carrying out de-radicalization in an evolutionary manner. Islamic boarding schools are not only educational institutions but also religious and social religious broadcasting institutions. Miftahul Ulum Lumajang Islamic Boarding School, through the Teaching and Learning Task Agency (TMTB) and Dai, since 1965 the Miftahul Ulum Lumajang Islamic Boarding School has sent hundreds of Teachers / Ustadz Tasks and Dai. Based on the report archive of the Agency for Teaching and Learning Tasks (TMTB) and Dai Miftahul Ulum, it can be specified that in 2017 as many as 433 Assigned Teachers / Ustadz and Dai were sent. In 2018 they sent 417 Tasks and Dai, the last year teaching 2019, officially released 404 Dai to six regions in Indonesia. Namely, East Java, Central Java, West Kalimantan, East Nusa Tenggara (NTT), Bali, and Papua. ${ }^{5}$ Graduates of the Miftahul Ulum Lumajang Islamic Boarding School from the Tsanawiyah level must carry out teaching assignments for one year in various remote areas. This is a requirement for obtaining a diploma. ${ }^{6}$

Walter Shewhart, with the "Plan proposed the first model in the quality assurance application, Do Check, Act" approach (planning, implementing, evaluating, following up and improving) or abbreviated as PDCA. However, in its development, the PDCA analysis

${ }^{1}$ Bagus Takwin and others, 'Studi Tentang Toleransi Dan Radikalisme Di Indonesia: Pembelajaran Dari 4 Daerah Tasikmalaya, Jogjakarta, Bojonegoro Dan Kupang', 2016, vi-viii.

${ }^{2}$ http://wahidfoundation.org/index.php/publication/index/report

${ }^{3}$ Noory Okthariza, 'Laporan Riset Intoleransi Dan Radikalisme Di Kalangan Perempuan', February, 2019, o-17 <https://doi.org/10.13140/RG.2.2.30064.10246>.

${ }^{4}$ Saifuddin. Radikalisme Islam Di Kalangan Mahasiswa (Sebuah Metamorfosa Baru). Jurnal Analisis, Volume XI, Nomor 1, Juni 2019. Universitas Islam Negeri Sunan Kalijaga Yogyakarta

${ }^{5}$ Dokumen. Laporan pemberangkatan Guru tugas dan Dai 2019. Sidogiri Pasuruan. 21 Oktober 2019

${ }^{6}$ Muhammad Ma'ruf, 'Eksistensi Pondok Pesantren Sidogiri Pasuruan Dalam Mempertahankan Nilai-Nilai Salag Di Era Globalisasi', Jurnal EVALUASI: Pendidikan Dan Pesantren, 01.02 (2017), 167-84 <https://doi.org/10.1017/CBO9781107415324.004>. 
methodology is more commonly referred to as the "Deming cycle". PDCA is a quality assurance flow that aims to make continuous improvements without stopping: ${ }^{7}$

1. Planning goals or objectives and what processes are needed to identify the results that are following the specified objectives. The purpose of planning is to identify problems that may arise and draw conclusions on the factors that influence the emergence of problems.

2. Do means taking action from a predetermined planning process. This process indicator has also been defined in the planning stage. The plans that have been previously determined are gradually realized by striving for all plans to be carried out efficiently and effectively.

3. Check means checking the results of the action and analyzing the level of target achievement, and following up with the preparation of the results report. This stage is done by comparing the quality of the product results with a predetermined standard, then analyzing and compiling a report on failure and then diagnosing the cause of failure.

4. Action means conducting a total evaluation of the achievement of goals and processes then following up with corrective actions. If then what has been done there are deficiencies, then it is followed up with corrective actions to reduce the re-emergence of the same problem or set new targets for the next improvement.

From this description, the researcher is interested in taking the research location at the Miftahul Ulum Lumajang Islamic boarding school because the pesantren has a quality assurance standard for the regeneration of ulama 'and dai with systemized characteristics, so that the three pesantren can contribute to community service in spreading Islamic values. rahmatan lil alamin and preventing the growth of radicalism in Indonesia.

\section{Research Method}

This type of research is a case study. Creswell argues that the focus of case studies is the specification of cases in an event, whether it includes individuals, cultural groups or a portrait of life. ${ }^{8}$ The data used three techniques, namely: (1) in-depth interviews; (2) non-participant observation and (3) documentary study (study of documents) the natural setting that exists on the research subject as a source of direct data in the form of words ${ }^{9}$, actions and documents as well as data- other supporting data.

This research will find and describe the data comprehensively and comprehensively quality assurance cadre of assisted teachers at Miftahul Ulum Lumajang Islamic Boarding School. In a study of this, the data analysis since collecting data as a whole checked back. Recurring time researchers match the data obtained, systematized, interpreted as logical for the sake of the legitimacy and credibility of the data obtained by researchers field.

Checking the validity of the data is the part that is very important and not is separated from research qualitative. According to Lincoln and Guba that the implementation of checking the validity of the data is based on four criteria, namely the degree of credibility, transferability, dependability and confirmability.For the inside view, the credibility of the data in the study of qualitative researchers use several ways as follows: first, triangulation or inspection / checking the validity of the data by using : (1) many sources of data, (2) many methods of collection to confirm the data and (3) much time ${ }^{10}$. Second, conduct peer debriefing, namely by involving other people to criticize the results and the process of research

\footnotetext{
${ }^{7}$ Matovu Musa, 'An Analysis of Quality Assurance Key Performance Indicators in Research in Ugandan Universities', International Journal of Instruction, $12.1 \quad$ (2019), 1567-84 <https://doi.org/10.29333/iji.2019.12110oa>.

${ }^{8}$ Mimansha Patel, 'Exploring Research Methodology: Review Article', International Journal of Research and Review, 6.3 (2019), 48-55.

${ }^{9}$ Greet Peersman, 'Data Collection and Analysis Methods', Revista Latinoamericana de Psicologia, 34.3 (2002), 241-49.

${ }^{10}$ S. Hadi, 'Pemeriksaan Keabsahan Data Penelitian Kualitatif, Jurnal Ilmu Pendidikan Universitas Negeri Malang, 22.1 (2017), 109874 <https://doi.org/10.17977/jip.v22i1.8721>.
} 
that the researchers did. For this reason, the researcher positions the proposed supervisor as a discussion partner. Thirdly, being and doing activities of the field for a relatively long time, understanding and appreciating quality assurance cadre of assisted teachers at Miftahul Ulum Lumajang Islamic Boarding School. In qualitative research, this activity is commonly referred to as prolonged engagement.

\section{Findings and Discussion}

As for the quality assurance standards for the regeneration of da'i at the Miftahul Ulum Lumajang Islamic Boarding School, including the cadres, namely the caregivers of the Islamic boarding school, the object of regeneration is santri, the cadre tool is the Islamic boarding school curriculum.

1. First on the Quality Assurance of Cadre

In an Islamic boarding school, Kiai is a centre that will determine the direction and sustainability of the boarding school in the future. This is related to the leadership model applied by a Kiai in the cottage. Is it a democratic leadership model, authoritarian or other? Then this will also affect the development of the cottage, especially in the implementation of teaching and learning programs. The caretaker of the Miftahul Ulum Lumajang Islamic Boarding School is in a cadre position, and he is KH. Ma'sum Madyari, M.Ag.

KH. Ma'sum Madyari, M.Ag is a gentle figure, generous and friendly to the students. He has the charisma of a Kiai who is so tawadhu that his students so respect him. Ust. Thoriqul Huda occupies a position as a caretaker companion, where he directly monitors and directs activities at Miftahul Ulum Islamic Boarding School. He is a figure whose leadership tends to be salafi and wishes that when the students have chosen a boarding house at the Miftahul Ulum Lumajang Islamic Boarding School, the students must place teaching and learning activities Islamic Boarding School first in the priority scale of the students. His thinking tends to be more rigid, which may be due to his educational background in a pure salaf Islamic boarding school. This leadership model affects the perceptions of the santri, who are non-santri students who are specifically lodged." Students tend to think actively and more freely so that sometimes the policies issued by the caretaker companions feel heavy on the shoulders of the students. This affects the students' awareness in participating in Pondok activities and complying with the rules that have been set.

There has been a shift in the leadership model from the early days of cottage development around 2000 to early 2014, with a period of leadership after that to the present. This is because the head of the cottage, originally the nanny's son-in-law, is now being replaced by the nanny's son. This impacts the leadership model, which at the same time influences the establishment of the existing cottage curriculum.

Based on the indicators of Islamic boarding schools with types or types of Islamic boarding schools classified by the head of the board, Ustadz Zainuddin, M.Pd.I, categorized Islamic boarding schools into three categories, namely traditional, modern and a combination of traditional and modern Islamic boarding schools. The Miftahul Ulum Lumajang Islamic Boarding School has experienced a shift in the type of Islamic boarding school, from a mixed traditional and modern (semi-modern) Islamic boarding school to a traditional Islamic boarding school (salaf). ${ }^{12}$

The Miftahul Ulum Islamic Boarding School, as a combination of traditional and modern at the beginning of its development, was marked by the adoption of a more

\footnotetext{
${ }^{11}$ Rizka Dwi Seftiani and others, 'The Implementation of Internal Quality Assurance System at Islamic School', 258.Icream 2018 (2019), 256-6o <https://doi.org/10.2991/icream-18.2019.52>.

${ }^{12}$ Nurfuadi Nurfuadi, 'The Development of Teachers' Pedagogical Competencies of Islamic Religious Education Based on Learning Quality Management', Jurnal Iqra': Kajian Ilmu Pendidikan, 5.2 (2020), 151-63 <https://doi.org/10.25217/ji.v5i2.1014>.
} 
modern general learning method and curriculum as a complement to or in addition to the classical book studies that are characteristic of the Salaf Islamic boarding school. These additional programs include football and a workshop for students from all over Lumajang with Prof. Dr. H. Imam Mawardi, MA. The Yellow Book Social Studies Institute (LKS2K), Miftahul Ulum Spiritual Network, language programs such as Arabic and English development institutes, computerization, internalization, Rebana Al-Mahboeb Group, Alihwan Cooperative, An-Najwa Bulletin, which is distributed every Friday. in several mosques in Lumajang and sports at Al-Miftah FC. There is a unique knowledge embodied in the Miftahul Ulum hisab institution; with this institution, it is hoped that it can produce cadres of rukyah reckoning experts who have been considered rare (documentation of the Miftahul Ulum Lumajang Islamic Boarding School in 2011).

Currently, the Miftahul Ulum Lumajang Islamic Boarding School is more focused on the study of the yellow book. The existing program is limited to the study of the yellow book through the bandongan, sorogan and memorization methods, which are carried out in the recitation of children after Maghrib and madrasah diniyyah after Isha.

2. Quality Assurance on the object of regeneration

Santri are the objects of da'i regeneration in Islamic boarding schools. They are the main target of human beings who will benefit the country, nation and religion. The number of students at the Miftahul Ulum Lumajang Islamic Boarding School is 130 male students and 112 female students. Santri have participated in a series of activities that the caregiver has scheduled through the authority of the management. Whether it is daily, weekly, monthly or yearly activities, in this case, the students participated quite well. Although they are also busy with class schedules at their respective campuses, they are still actively participating in recitation or activities at the Islamic boarding schools. ${ }^{13}$ Santri realizes that the Koran is one of the obligations that must be carried out because of th

3. Quality Assurance in the Cadre of the Curriculum

The Pondok Pesantren curriculum occupies a position as a means of regeneration. This curriculum is realized through scheduling recitations and other santri activities. The recitation schedule is designed according to the class schedules of the students, who are predominantly students. The activities of the Islamic boarding school start from the evening prayer until the dawn prayer only. The learning methods applied at the Miftahul Ulum Lumajang Islamic Boarding School consist of bandongan (wetonan), sorogan and rote memorization. These three methods are the methods chosen to equip students to increase their knowledge of Islam. ${ }^{14}$ Meanwhile, other methods such as discussion among students were included in the agenda of bahtsul matsail (discussion of specific problems) and madrasah diniyyah, although not yet dominant, because they were adapted to the creativity of the teachers.

The discussion method will help train the courage of the students in expressing their opinions, as well as training the students to be able to listen to lessons well The curriculum as a regeneration tool is classified into two parts, namely First, the Formal Curriculum consists ofe status of the santri and the awareness of being a rational human being :

a. Khithobah training

Khitobah ranks first as a cadre program for students as prospective preachers because this program directly directs the students to learn how to rhetoric in oral da'wahincluded in the preparation of methods and techniques, where the lecture or speech consists of at least three essential parts, namely the opening (muqoddimah), content and

\footnotetext{
${ }^{13}$ Rukhaini Fitri Rahmawati, 'Kaderisasi Dakwah Melalui Lembaga Pendidikan Islam', Tadbir: $\begin{array}{lllll}\text { Jurnal Manajemen } & \text { Dakwah, } & 1.1 & \text { (2016), }\end{array}$ <https://journal.iainkudus.ac.id/index.php/tadbir/article/view/2387/1910>.

${ }^{14}$ Abdullah Abdulrahman Alqarni, 'C Urriculum Design Quality Assurance At S Audi E Lectronic U Niversity', October, 2016.
} 
closing. This training is held every two weeks, the schedule for female students is every Tuesday night, and male students are every Thursday night. Through this training, students are trained to have the courage to convey some Islamic teaching materials that can be adapted to the current state of society so that one day the students will have provision for da'wahbilkalam. This training is also a provision for the preacher as a community builder and developer, as stated by Abdullah NasihUlwan One of the da'i's duties is an orator (khatib). So the preachers must be good at conveying da'wah messages utilizing kalam (speaking). ${ }^{15}$

b. Kitab Kuning study

In addition to the speech training, there is a provision in terms of Islamic material obtained through the yellow book study program and other additional material through the bandongan, sorogan and rote methods. The yellow books studied at the MiftahulUlum Islamic Boarding School include Tafsirjalalain, MinhajulQawim, TajridusShorih, RiyadlusSholihin, Ibnu „Aqil, AkhlaqullilBanaat, SafinatunNajaah, TuhfathulAtfalSho, Jurumiyah, ImrithiDaruri Iman, Amstilatu Iman, and others. This helps students as prospective da'i cadres in understanding Islamic teachings before they are conveyed to others. Da'i has the function of amarma'rufnahyimunkar, so it is clear that prospective da'i cadres must first distinguish which one is ma'ruf and which one is munkar. Therefore, to achieve this, the deepening of Islamic teachings needs to be carried out, and the study of the yellow book is one of the efforts. In addition, this yellow book study is intended to equip students in building intellectual strength as one of the requirements for a preacher as a community builder and developer. ${ }^{16}$

c. Learning evaluation

This final exam helps the students be motivated to seriously participate in the recitation programs included in the Islamic boarding school curriculum. Santri, as da'i cadre candidates, is expected to be serious in listening to what the teacher says when the recitation takes place, then repeating the lesson outside the recitation time so that the da'wah material can be understood and practised. In addition to evaluation through oral and written examinations, evaluation is also carried out through religious competitions such as young preachers, memorization of tasrifiyah, polar bahtsul, first rank, and others. This competition can also motivate students to show courage and knowledge, to maximize what they have learned over the past year. ${ }^{17}$

Second, the Miftahul Ulum Islamic boarding school strengthens the quality assurance of the cadre of ulama by implementing the Hidden Curriculum, among others, in the following ways:

a. Assigning students to both learning and teaching

Santri, while studying, listen to the explanations given by the teacher when the recitation takes place. Then, when the students teach, the students have to understand the material first before it is conveyed to other students. More importantly, it can make the listening students understand. The Miftahul Ulum Islamic Boarding School applies a method to improve mental speech and material maturity through the students and teachers program. Some students are assigned the task of teaching other students. The material taught is obtained from the yellow book, both in fiqh such as Safinatun Najaah, monotheism like Tijaanud Daruri, morals like Akhlaqul lil Banaat, hadiths like Lubaabul Hadith, nahwu like Jurumiyyah and Nahwu. In this case, there are two benefits at once,

\footnotetext{
${ }^{15}$ Abdul Kholiq, 'Kadersisasi Da'I Moderat Era Milenial Di Pengurus Cabang Nahdlatul Ulama Kabupaten Kendal', An-Nida: Jurnal Komunikasi Islam, $11.2 \quad$ (2019) <https://doi.org/10.34001/an.v11i2.1028>.

${ }^{16}$ Sigit Tri Utomo, 'Quality Management at Islamic School', Attarbiyah, 3.1 (2018), 113 $<$ https://doi.org/10.18326/attarbiyah.v3i1.109-130>.

${ }^{17}$ Uswatun Khasanah, 'Kaderisasi Da'iyah Pesantren Ulil Albab Ngaliyah Semarang', 121311079, 2016.
} 
namely mental training and careful material preparation. A teacher or mudarris in the teaching process requires steady preparation from a mental and material perspective. ${ }^{18}$ So this program has benefits that are not much different from khitobah. Concerning the learning process and how matter can be absorbed into our brains, humans learn to observe the environment or what other people convey through several ways such as hearing and seeing.

So it is only natural if caregivers also consider this method as one of the essential programs in mentally building and gaining deeper insight into students. If the santri were only tasked with receiving material, through this program, the santri also occupied a position as material givers or transmitters of Islamic religious teachings, which in the science of da'wah is called da'i or da'wah subjects. Pesantren is a small scope of mad'u, the recipient of the message of da'wah. Furthermore, through this program, students are expected to be more ready to preach in the broader scope, namely being able to preach on the broader community.

b. Mujahadah (Guidance of Nafs)

This sunnah practice is meant for caregivers to strengthen students' spirituality through prayers of desire and dhikr together every Monday, one month. Dhikr-dhikr recited include Istighfar, Sholawat and Ayat Kursi. Students are constantly reminded to surrender and seek help from Allah SWT in all matters, including studying or working through this activity. The more students trust in God; then indicates the more robust their faith in God. Because of that faith as well, students can slowly learn to control their passions. According to Ust. Zainuddin (Interview on September 14, 2020): The Mujahadah earnestly asked Allah, what is best for us and also good according to Allah SWT, including in the prayer the caregivers and students asked for Pondok Pesantren Miftahul Ulum to be a hut who are blessed and print graduates who have knowledge that is useful for the life of this world and the hereafter. ${ }^{19}$

c. Maintain traditions and good relations with the community

Mingling with the broader community is the first step to fostering good relations with people outside the Islamic boarding school. One of the methodological competencies that a preacher must have is that the preacher must find and obtain information about the objective and subjective characteristics of the da'wah object and its environmental conditions. ${ }^{20}$ Participating with current events in society such as wedding recitations, tahlilan, circumcision, hajj or new house tasyakuran, childbirth tasyakuran, is an opportunity for prospective da'i cadres, in this case, students, to seek and explore this information. Moreover, Javanese society is thick with traditions and rituals that need to understand the nature and purpose of the da'i cadres.

The research findings are in line with the theory adapting Edward Sallis' theory of organizing education so that it can be described that the model for organizing quality assurance in the education dimension can be carried out in the following stages: ${ }^{21}$ a) We are planning the quality of human resource learning. The educational organization is the preparation of steps and processes to produce products that suit customers' needs, both at strategic and technical levels. This assumes that Islamic boarding schools in Indonesia must

\footnotetext{
${ }^{18}$ Ibid. Alqarni.

${ }^{19}$ Siti Nazratul Ain Mohd Arifin and Salasiah Hanin Hamjah, 'Aplikasi Tazkiyah Al-Nafs Menerusi Mujahadah Al-Nafs Dalam Kaunseling', Fikiran Masyarakat, 5.2 (2017), 57-61.

${ }^{20}$ Muh Arsyad and Bahaking Rama, 'Urgensi Pendidikan Islam Dalam Interaksi Sosial Masyarakat Soppeng: Upaya Mewujudkan Masyarakat Madani', Al-Musannif: Journal of Islamic Education and Teacher Training, 1.1 (2019), 1-18 <https://jurnal.mtsddicilellang.sch.id/index.php/al-musannif>.

${ }^{21}$ Lucien Bollaert, 'Quality Assurance (QA) in Europe (2005 - 2015). From Internal and Institutional to External and International', Journal of the European Higher Education Area, 3, $2014,1-24$.
} 
have high creativity and innovation in designing various procedures for implementing the quality of learning to produce qualified ulama cadres. b) Implementation of quality human resources learning. The educational, organizational structure is the implementer of the quality plan, both at strategic and technical levels, accompanied by careful supervision of all processes that occur so that there are no errors. Thus the quality of the learning products is guaranteed. c) Evaluate the quality of human resource learning. Educational organizations seek to correct weaknesses that occur or make quality innovations so that educational products can be superior, both at the technical, operational and strategic levels. In that context, educational organizations must always have a level of transparency and accountability of each activity, both internally and externally, so that the quality of processes and products produced by educational organizations is following predetermined standard measures.

\section{Conclusion}

The quality assurance system at the RaudatulUlum Islamic Boarding School involves several elements that are arranged in such a way as to form a system model that aims to produce da'i cadres who have good knowledge and knowledge. The da'i cadre system model consists of input, process and output. Input is all students or prospective da'i cadres who are trained and educated to become loyal da'wah cadres in preaching one day. The process is regeneration carried out by the caregiver as a cadre to the cadre object, namely the students. This regeneration process uses the formal curriculum and hidden curriculum applied to recitation programs and other non-formal programs. While the output itself is preacher cadres who have finished being cadres related to the Islamic boarding school, the output is the alumni who have graduated and are ready to preach in the community. The elements of the da'i cadre system at the RaudatulUlum Islamic Boarding School include cadres, namely the caregivers of the Islamic boarding school, the object of regeneration is the santri, and the cadre tool is the Islamic boarding school curriculum.

\section{References}

Alqarni, Abdullah Abdulrahman, 'C Urriculum Design Quality Assurance At S Audi E Lectronic U Niversity', October, 2016

Arsyad, Muh, and Bahaking Rama, 'Urgensi Pendidikan Islam Dalam Interaksi Sosial Masyarakat Soppeng: Upaya Mewujudkan Masyarakat Madani', Al-Musannif: Journal of $\begin{array}{llllll}\text { Islamic Education and Teacher Training, } 1.1 & \text { (2019), }\end{array}$ $<$ https://jurnal.mtsddicilellang.sch.id/index.php/al-musannifs

Bollaert, Lucien, 'Quality Assurance (QA) in Europe (2005 - 2015). From Internal and Institutional to External and International', Journal of the European Higher Education Area, 3, 2014, 1-24

Greet Peersman, 'Data Collection and Analysis Methods', Revista Latinoamericana de Psicologia, 34.3 (2002), 241-49

Hadi, S., 'Pemeriksaan Keabsahan Data Penelitian Kualitatif', Jurnal Ilmu Pendidikan Universitas Negeri Malang, 22.1 (2017), 109874 <https://doi.org/10.17977/jip.v22i1.8721> 
Khasanah, Uswatun, 'Kaderisasi Da'iyah Pesantren Ulil Albab Ngaliyah Semarang', 121311079, 2016

Kholiq, Abdul, 'Kadersisasi Da'I Moderat Era Milenial Di Pengurus Cabang Nahdlatul Ulama Kabupaten Kendal', An-Nida: Jurnal Komunikasi Islam, 11.2 (2019) <https://doi.org/10.34001/an.v11i2.1028>

Ma'ruf, Muhammad, 'Eksistensi Pondok Pesantren Sidogiri Pasuruan Dalam Mempertahankan Nilai-Nilai Salag Di Era Globalisasi', Jurnal EVALUASI: Pendidikan Dan Pesantren, 01.02 (2017), 167-84 <https://doi.org/10.1017/CBO9781107415324.004>

Musa, Matovu, 'An Analysis of Quality Assurance Key Performance Indicators in Research in Ugandan Universities', International Journal of Instruction, 12.1 (2019), 1567-84 $<$ https://doi.org/10.29333/iji.2019.12110oa>

Nurfuadi, Nurfuadi, 'The Development of Teachers' Pedagogical Competencies of Islamic Religious Education Based on Learning Quality Management', Jurnal Iqra': Kajian Ilmu Pendidikan, 5.2 (2020), 151-63 <https://doi.org/10.25217/ji.v5i2.1014>

Okthariza, Noory, 'Laporan Riset Intoleransi Dan Radikalisme Di Kalangan Perempuan', February, 2019, 0-17 <https://doi.org/10.13140/RG.2.2.30064.10246>

Patel, Mimansha, 'Exploring Research Methodology: Review Article', International Journal of Research and Review, 6.3 (2019), 48-55

Rahmawati, Rukhaini Fitri, 'Kaderisasi Dakwah Melalui Lembaga Pendidikan Islam', Tadbir: $\begin{array}{lllll}\text { Jurnal Manajemen } & \text { Dakwah, } & 1.1 & \text { (2016), } & \text { 147-66 }\end{array}$ <https://journal.iainkudus.ac.id/index.php/tadbir/article/view/2387/1910>

Seftiani, Rizka Dwi, Sobarul Hakim, Riki Rikjan, and Muflihatusy Syarifah, 'The Implementation of Internal Quality Assurance System at Islamic School', 258.Icream 2018 (2019), 256-6o <https://doi.org/10.2991/icream-18.2019.52>

Siti Nazratul Ain Mohd Arifin, and Salasiah Hanin Hamjah, 'Aplikasi Tazkiyah Al-Nafs Menerusi Mujahadah Al-Nafs Dalam Kaunseling', Fikiran Masyarakat, 5.2 (2017), 57-61

Takwin, Bagus, Amin Mudzakkir, Hairus Salim, Moh Iqbal Ahnaf, and Ahmad Zainul Hamdi, 'Studi Tentang Toleransi Dan Radikalisme Di Indonesia: Pembelajaran Dari 4 Daerah Tasikmalaya, Jogjakarta, Bojonegoro Dan Kupang', 2016, vi-viii

Utomo, Sigit Tri, 'Quality Management at Islamic School', Attarbiyah, 3.1 (2018), 113 <https://doi.org/10.18326/attarbiyah.v3i1.109-130> 